\title{
Keefektifan Tingkatan Pembelajaran Inkuiri (Levels Of Inquiry) terhadap Peningkatan Keterampilan Proses Sains pada Siswa dengan Pengetahuan Awal Berbeda
}

\author{
Salim, Suryaman, Retno Danu Rusmawati \\ Universitas PGRI Adi Buana, Pascasarjana, Teknologi Pendidikan
}

\section{Edcomtech}

\section{Jurnal Kajian}

Teknologi Pendidikan

Volume 4, No 2, Oktober 2019

96-108

Submitted 03-05-2019

Accepted 28-08-2019

Corresponding Author

Salim

alimsalim650@gmail.com

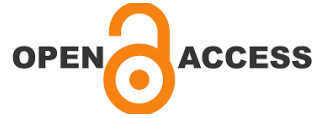

\begin{abstract}
Abstrak
Penelitian ini bertujuan untuk mengetahui perbedaan keefektifan pembelajaran inkuiri dalam beberapa tingkatan terhadap peningkatan keterampilan proses sains dengan pengetahuan awal berbeda. Rancangan penelitian menggunakan quasi eksperimen dengan perlakuan prates-pascates pada kelompok kontrol dan kelompok eksperimen. Siswa kelas X MAN Sampang dan SMAN 1 Sampang tahun pelajaran 2018/2019. Sampel di kelompokkan dalam tiga kelompok perlakuan. Kelompok eksperimen 1 diterapkan pembelajaran inkuiri tingkat 3 (PIT-3), kelompok eksperimen 2 diterapkan pembelajaran inkuiri tingkat 4 (PIT4) dan kelompok kontrol diterapkan pembelajaran inkuiri tingkat 2 (PIT-2). Uji keterampilan proses sains menggunakan soal obyektif pilihan ganda dengan reliabilitas tes sebesar 0,77 . Analisa data menggunakan uji ANOVA. Penelitian ini menyimpulkan pembelajaran inkuiri tingkat 2 (PIT-2), tingkat 3 (PIT-3) dan tingkat 4 (PIT-4) mempunyai perbedaan keefektifan terhadap peningkatan keterampilan proses sains. Peningkatan keterampilan proses sains siswa dengan pengetahuan awal berbeda, paling efektif pada penerapan pembelajaran inkuiri tingkat 3 (PIT-3), siswa dengan pengetahuan awal tinggi dan rendah memperoleh Gain peningkatan lebih tinggi dari penerapan pembelajaran inkuiri tingkat 2 (PIT-2) dan tingkat 4 (PIT-4).
\end{abstract}

Kata Kunci: Levels of inquiry, pengetahuan awal, keterampilan proses sains.

\begin{abstract}
This study aims to determine the differences in the effectiveness of inquiry learning on several levels towards improving science process skills with different initial knowledge. The study design uses quasi-experimental treatment with pre-posttates in the control group and the experimental group. Class X MAN Sampang and SMAN 1 Sampang students in 2018/2019 school year. Samples were grouped into three treatment groups. The experimental group 1 applied level 3 inquiry learning (PIT-3), the experimental group 2 applied level 4 inquiry learning (PIT-4) and the control group applied level 2 inquiry learning (PIT-2). The science process skills test uses multiple choice objective questions with a test reliability of 0.77. Data analysis uses ANOVA test. This study concludes level 2 (PIT-2), level 3 (PIT-3) and level 4 (PIT-4) inquiry learning has a difference in effectiveness in improving science process skills. Improved science process skills of students with different initial knowledge, most effective in the application of inquiry level 3 (PIT-3) learning, students with high and low initial knowledge gain a higher gain than the application of level 2 (PIT-2) and level 4 inquiry learning (PIT-4).
\end{abstract}

Keywords: Levels of inquiry, pengetahuan awal, keterampilan proses sains. 


\section{LATAR BELAKANG}

Sebagai cabang dari ilmu pengetahuan alam (IPA), ilmu kimia diperoleh dan dikembangkan dari kegiatan eksperimen atas fenomena alam yang terjadi untuk menjawab pertanyaan apa, mengapa dan bagaimana fenomena alam itu terjadi. Materi dalam ilmu kimia sangat luas yang dapat berupa konsep, fakta, hukum, aturan, teori, prinsip dan soalsoal kimia.

Banyak konsep dalam ilmu kimia yang bersifat abstrak dan umumnya siswa sulit untuk memahaminya (Hanson. dkk. 2011). Selain memiliki konsep-konsep yang rumit, penyelesaian soal-soal kimia juga memerlukan keterampilan matematika. Kemampuan siswa untuk menguasai materi sebelum berganti ke materi selanjutnya sangat dibutuhkan dalam belajar kimia karena materi ilmu kimia bersifat berurutan, berjenjang, kompleks dan saling berhubungan antar materi. (Kean \& Middlecamp. 1985). Di SMA/MA materi kimia merupakan materi yang relatif baru bagi siswa kelas X. Di tingkat SMP/MTs, siswa hanya sedikit mendapat materi kimia yang terintegrasi dalam pelajaran IPA.

Penelitian Ristiyani \& Bahriah (2016) menunjukkan rata-rata persentase siswa yang mengalami kesulitan belajar kimia sebesar 70,15\% (kategori sedang). 74,5\% kesulitan belajar siswa disebabkan oleh faktor fisiologis karena keterbatasan jasmani/pancaindra dengan kategori tinggi, 69,78\% disebabkan faktor psikologi dengan kategori sedang, 68\% disebabkan faktor sosial dengan kategori sedang, 58,75\% disebabkan faktor sarana dan prasarana dengan kategori sedang. $77 \%$ disebabkan faktor metode belajar dengan kategori tinggi dan $77,17 \%$ disebabkan oleh faktor guru dengan kategori tinggi. Kesulitan siswa terhadap kimia berdampak pada aktifitas, minat dan hasil belajar yang rendah.

Rendahnya hasil belajar siswa menurut Wedi (2016) disebabkan kesalahan penerapan strategi dan metode pembelajaran, terdapat kesenjangan penggunaan suatu metode antara kesahihan secara teoritik dan ketidakefektifan secara praktis. Ketepatan pemilihan metode pembelajaran dan keseriusan penggunaan metode untuk kesempurnaan penerapannya akan berpengaruh terhadap peningkatan prestasi belajar dan kualitas pembelajaran. Menurut Muslich (2007) pembelajaran umumnya hanya menonjolkan hafalan dan tidak disertai pemahaman mendalam, pembelajaran hanya berorientasi pada penguasaan materi.

Setyosari (2014) menyatakan pembelajaran yang efektif tidak bisa dilepaskan dari pembelajaran yang berkualitas. Kualitas hasil belajar tergantung pada efektifitas pembelajaran yang terjadi atau diterjadikan di dalam proses pembelajaran itu sendiri. Pembelajaran dikatakan efektif jika tujuan pembelajaran yang diharapkan dapat tercapai.

Kegiatan menemukan masalah, mengumpulkan fakta, membuat asumsi, mengendalikan variabel, memvariasi variabel, melakukan observasi, pengukuran, inferensi, memprediksi, mengumpulkan data dan mengolah data hasil observasi/pengukuran, menarik kesimpulan dan mengkomunikasikan, merupakan cara berpikir, bersikap dan langkah-langkah kegiatan ilmiah yang diterapkan dalam pembelajaran kimia sebagai proses/metode penyelidikan melalui pembelajaran discovery/inquiry.

Karakteristik ilmu kimia sebagai sikap, proses dan produk, harus diperhatikan dalam kegiatan pembelajaran dan penilaian hasil belajar. Pembelajaran kimia perlu diarahkan pada kegiatan yang mendorong siswa aktif melibatkan keterampilan dan penalaran yang mengintegrasikan proses penemuan melalui kegiatan praktikum. Guru dituntut untuk melakukan strategi pembelajaran yang kreatif dan inovatif agar siswa mampu menemukan pengetahuan barunya sendiri.

Kurikulum 2013 menerapkan pendekatan ilmiah (saintifik) yang memiliki relevansi dengan penilaian autentik (authentic assessment) dimana penilaian menjadi bagian integral dari pembelajaran. Pembelajaran berorientasi pada proses bukan pada hasil. Pendekatan saintifik dapat diterapkan dengan penerapan model pembelajaran berbasis penyingkapan/ penelitian (discovery/inquiry)

Sutman, Schmuckler \& Joyce (2008) menyatakan pembelajaran inkuiri meliputi tiga fase yaitu fase sebelum pengalaman laboratorium (pre-laboratory phase), fase pengalaman laboratorium (laboratory phase) 
dan fase sesudah pengalaman laboratorium (post-laboratory phase). Fase-fase ini dibagi menjadi lima tahapan atau langkah selama periode pembelajaran. Tahapan/ langkah pembelajaran inkuiri meliputi (1) pengajuan masalah/topik untuk diselidiki (2) merencanakan prosedur penyelidikan (3) melakukan kegiatan percobaan (4) kesimpulan (5) tindak lanjut.

Berdasarkan lima tahapan/langkah dari fase pembelajaran inkuiri, Sutman, Schmuckler \& Joyce (2008) mengklasifikasikan pembelajaran inkuiri dalam enam tingkat penyelidikan, yang satu sama lain berbeda dalam peran guru dan siswa. Keterlibatan guru dalam pembelajaran yang dilakukan akan semakin berkurang sesuai dengan tingkat penyelidikan yang sedang berlangsung. Semakin tinggi tingkat penyelidikan, semakin aktif siswa dalam pembelajarannya, sebaliknya semakin rendah tingkat penyelidikan, semakin besar peran guru dalam pembelajaran. Tingkatan pembelajaran inkuiri menurut Sutman, Schmuckler \& Joyce (2008) disajikan dalam tabel 1.

Tabel 1. Matriks Tingkatan Pembelajaran Inkuiri

\begin{tabular}{|c|c|c|c|c|c|}
\hline \multirow{2}{*}{$\begin{array}{l}\text { Tingkatan/ } \\
\text { level } \\
\text { inkuiri }\end{array}$} & \multicolumn{2}{|c|}{$\begin{array}{c}\text { Sebelum-Pengalaman } \\
\text { laboratorium }\end{array}$} & \multirow{2}{*}{\begin{tabular}{l}
\multicolumn{1}{c}{$\begin{array}{c}\text { Pengalaman } \\
\text { Laboratorium }\end{array}$} \\
Melakukan \\
prosedur, \\
mengumpulkan \\
dan \\
menganalisis \\
data dari \\
pengamatan
\end{tabular}} & \multicolumn{2}{|c|}{ Sesudah-Pengalamam Laboratorium } \\
\hline & $\begin{array}{l}\text { Pengajuan } \\
\text { masalah } \\
\text { untuk } \\
\text { dieksplorasi }\end{array}$ & $\begin{array}{l}\text { Perencanaan } \\
\text { prosedur } \\
\text { yang } \\
\text { digunakan } \\
\text { untuk } \\
\text { eksplorasi }\end{array}$ & & $\begin{array}{l}\text { Menjawab } \\
\text { pertanyaan } \\
\text { atau } \\
\text { menyimpulkan } \\
\text { yang } \\
\text { berhubungan } \\
\text { dengan } \\
\text { penyelidikan }\end{array}$ & $\begin{array}{l}\text { Mempertimbangkan } \\
\text { bagaimana } \\
\text { penemuan- } \\
\text { penemuan dapat } \\
\text { diterapkan atau } \\
\text { diarahkan ke } \\
\text { penyelidikan } \\
\text { lainnya }\end{array}$ \\
\hline 0 & Guru & Guru & Guru & Guru & Guru \\
\hline 1 & Guru & Guru & Guru & Guru & Siswa \\
\hline 2 & Guru & Guru & Guru & Siswa & Siswa \\
\hline 3 & Guru & Guru & Siswa & Siswa & Siswa \\
\hline 4 & Guru & Siswa & Siswa & Siswa & Siswa \\
\hline 5 & Siswa & Siswa & Siswa & Siswa & Siswa \\
\hline
\end{tabular}

Sumber: Sutman, Schmuckler \& Joyce (2008)

Setiap tingkat pembelajaran inkuiri yang dipilih harus sesuai dengan tingkat kompetensi dan pengalaman siswa. Llewellyn (2011) menyatakan bahwa keberadaan beberapa tingkat inkuiri memungkinkan bagi guru untuk dapat membangun investigasi dengan berbagai tingkat bimbingan sehingga siswa memiliki kesempatan untuk memilih tingkat yang sesuai untuk tahap perkembangan dan gaya belajar masing-masing. Dengan mengetahui tingkat kompetensi siswa, guru akan merasa mudah untuk merancang pembelajaran yang dibangun secara akurat yang memungkinkan siswa untuk mengembangkan peningkatan dalam tingkat keterampilan dan keahlian dalam pembelajaran sains agar proses pembelajaran inkuiri bisa berjalan dengan baik.

Abungu, dkk. (2014) menyatakan pengetahuan ilmiah yang berguna di masyarakat untuk memecahkan masalah bersumber dari keterampilan proses. Agar tujuan pembelajaran dapat tercapai, peningkatan dan pengembangan keterampilan proses siswa perlu untuk dilakukan dalam pembelajaran. Keterampilan kognitif berupa keterampilan berpikir logis, penalaran dan keterampilan pemecahan masalah semuanya bertumpu pada keterampilan proses sains. (Rauf, dkk. 2013). Menurut Sukarno, dkk (2013) Keterampilan proses sains dapat dikembangkan dengan lebih baik pada pembelajaran berbasis laboratorium. Data menunjukkan kegiatan pembelajaran yang mengembangkan keterampilan proses sains masih rendah, dengan rincian $43,38 \%$ pengembangan keterampilan sains dalam kegiatan belajar rendah, 30,43\% dengan pengembangan sedang dan $26,09 \%$ dengan pengembangan keterampilan sains dalam kegiatan belajartinggi. Kurangnya pemahaman 
dan pengetahuan guru dalam menerapkan pembelajaran yang mengembangkan keterampilan proses sains menjadi menjadi faktor penyebabnya.

Rustaman, dkk. (2005) menyatakan pengalaman langsung dalam kegiatan pembelajaran dapat mengembangkan keterampilan proses siswa. Pembelajaran yang condong ke arah pengalaman langsung adalah pembelajaran inkuiri. Pembelajaran inkuiri dapat memberikan kerangka kerja instruksional yang membantu untuk membuat yakin bahwa siswa mengembangkan lingkup intelektualnya yang lebih luas dan keterampilan proses ilmiah. (Wenning \& Mansoor, 2011)

Hasil penelitian Ergul, dkk. (2011) menyatakan keterampilan proses sains dapat ditingkatkan melalui penerapan metode inkuiri dalam pembelajaran. Matthew \& Kenneth (2013) menyimpulkan bahwa siswa yang diajarkan dengan strategi pembelajaran inkuiri terbimbing mempunyai keterampilan penalaran lebih baik dari siswa yang diajar dengan strategi konvensional. Hairani, dkk. (2016) menyimpulkan penerapan model pembelajaran inkuiri terbimbing, inkuiri terbimbing berbantuan mind mapping dan model pembelajaran langsung memberikan pengaruh yang berbeda terhadap keterampilan proses sains. Puspaningtyas \& Suparno (2017) menyimpulkan bahwa penerapan model inkuiri terbimbing dapat meningkatkan kemampuan analisis dan keterampilan proses sains dari pada model ekspositori.

Ariani, dkk. (2015) menyimpulkan terjadi peningkatan keterampilan proses sains sebesar $23,86 \%$ pada penerapan model inkuiri terbimbing. Iswatun, dkk. (2017) menyatakan gain peningkatan penerapan pembelajaran inkuiri terbimbing sebesar 0,52 dengan kriteria peningkatan sedang. Hardianti \& Kuswanto (2017) menyimpulkan bahwa ada perbedaan keefektifan yang signifikan antara pembelajaran inkuiri tingkat 2 , tingkat 3 dan 4 dalam meningkatkan keterampilan proses siswa. Penerapan pembelajaran inkuiri tingkat
3 lebih efektif dari pada pembelajaran inkuiri tingkat 2 dan tingkat 4 dalam meningkatkan keterampilan proses sains. Selain penerapan model pembelajaran, pengetahuan awal siswa juga berkontribusi terhadap hasil belajarsiswa. Hairani, dkk. (2016) menyimpulkan bahwa ada perbedaaan keterampilan proses sains yang disebabkan perbedaan pengetahuan awal siswa. Penelitian ini menunjukkan pembelajaran IPA memerlukan pengetahuan awal yang cukup untuk memudahkan siswa dalam belajar dan meningkatkan hasil belajar.

Berbeda dengan penelitian Hardianti \& Kuswanto (2017) disamping penerapan tingkatan pembelajaran inkuiri dalam kegiatan pembelajaran, penelitian ini melibatkan variabel moderator yang juga memberikan pengaruh terhadap peningkatan keterampilan proses sains yaitu pengetahuan awal siswa.

\section{METODE}

Rancangan penelitian yang digunakan adalah eksperimen semu (quasi experiment) dengan teknik prates dan pascates diberikan pada kelompok eksperimen dan kelompok kontrol sebelum dan sesudah perlakuan. Tabel 2 menunjukkan rancangan penelitian yang dilakukan.

Tabel 2. Rancangan Penelitian

\begin{tabular}{|l|c|c|c|}
\hline Kelompok & Prates & Perlakuan & Pascates \\
\hline Eksperimen 1 & $\mathrm{T}_{1}$ & $\mathrm{X}_{\mathrm{PIT}-3}$ & $\mathrm{~T}_{2}$ \\
\hline Eksperimen 2 & $\mathrm{T}_{1}$ & $\mathrm{X}_{\mathrm{PIT}-4}$ & $\mathrm{~T}_{2}$ \\
\hline Kontrol & $\mathrm{T}_{1}$ & $\mathrm{X}_{\mathrm{PIT}-2}$ & $\mathrm{~T}_{2}$ \\
\hline
\end{tabular}

\section{Keterangan:}

XPIT-2 : Pembelajaran inkuiri tingkat 2

XPIT-3 : Pembelajaran inkuiri tingkat 3

XPIT-4 : Pembelajaran inkuiri tingkat 4

T1 : Prates keterampilan proses sains

T2 : Pascates keterampilan proses sains

Tahapan kegiatan yang dilakukan, meliputi tahap persiapan, tahap pelaksanaan dan tahap akhir. Rincian tahapan kegiatan ditunjukkan pada gambar 1 . 


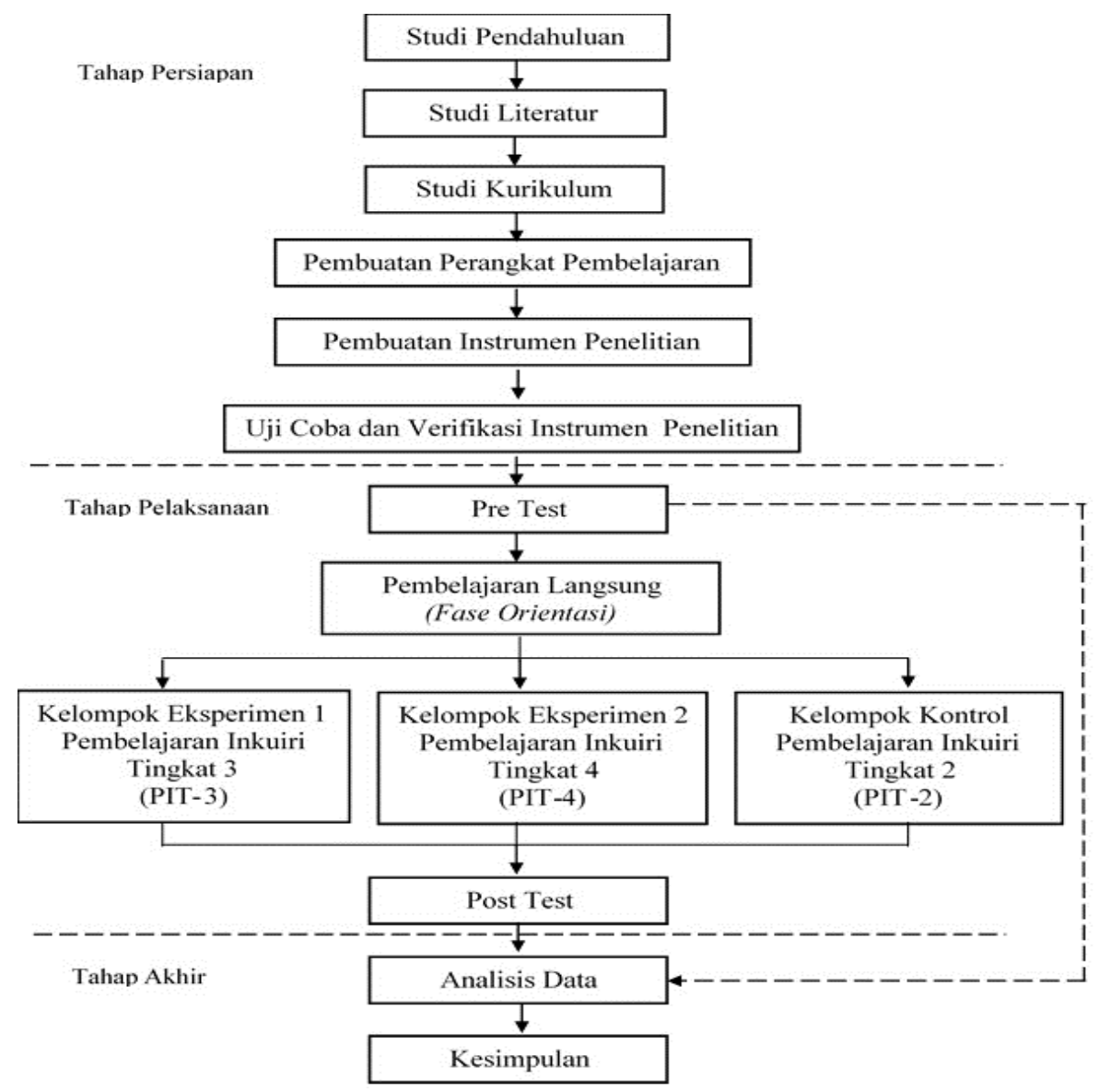

Gambar 1. Alur Kegiatan Penelitian

Keseluruhan subyek penelitian adalah siswa kelas X MAN Sampang dan SMAN 1 Sampang tahun pelajaran 2018/2019. Sampel penelitian diambil tiga kelas dari masing-masing sekolah.
Teknik cluster random sampling digunakan untuk menentukan sampel penelitian secara acak. Sampel penelitian dari kedua sekolah diperlihatkan pada tabel 3.

Tabel 3. Sampel Penelitian Dari MAN Sampang dan SMAN 1 Sampang

\begin{tabular}{lllcl}
\hline Sekolah & Kelompok & Kelas & $\begin{array}{c}\text { Jumlah } \\
\text { Siswa }\end{array}$ & Perlakuan \\
\hline MAN & Eksperimen 1 & X MIPA-4 & 24 & PIT-3 \\
Sampang & Eksperimen 2 & X MIPA-3 & 23 & PIT-4 \\
& Kontrol & X MIPA-2 & 23 & PIT-2 \\
\hline SMAN 1 & Eksperimen 1 & X MIPA-5 & 34 & PIT-3 \\
Sampang & Eksperimen 2 & X MIPA-3 & 34 & PIT-4 \\
& Kontrol & X MIPA-2 & 34 & PIT-2 \\
\hline \multicolumn{5}{c}{ Jumlah } \\
\hline
\end{tabular}


Sampel penelitian dari kedua sekolah berjumlah 172 siswa dengan rincian 70 siswa (40,70\%) dari MAN Sampang dan 102 siswa (59,30\%) dari SMAN 1 Sampang.

Dua macam instrumen digunakan dalam penelitian ini yaitu instrumen perlakuan yang berupa rencana pelaksanaan pembelajaran, lembar kegiatan siswa dan petunjuk praktikum yang telah divalidasi. Instrumen kedua adalah instrumen pengukuran yaitu tes keterampilan proses sains pada materi larutan elektrolit dan non elektrolit berupa tes obyektif pilihan ganda dengan satu jawaban benar dan empat jawaban sebagai pengecoh.

Penyusunan butir soal tes keterampilan proses sains mengacu pada berbagai sumber buku pelajaran kimia dengan mengembangkan indikator keterampilan proses sesuai permendikbud nomor 24 tahun 2016. Konsep keterampilan proses sains pada penelitian ini didasarkan pada pendapat Rustaman (2005) yang meliputi aspek mengamati (observasi), menafsirkan (interpretasi), mengajukan pertanyaan, menggunakan alat dan bahan, mengelompokkan (klasifikasi), berhipotesis, meramalkan (prediksi), merencanakan percobaan/penelitian, menerapkan konsep dan berkomunikasi.

Validitas butir soal, tingkat kesukaran, daya beda dan reliabilitas tes diketahui dengan verifikasi instrumen. Dari verifikasi instrumen diperoleh nilai reliabilitas tes sebesar 0,77 ( $\mathrm{r}$ hitung $>r$ tabel $(24: 0,05)=0,404)$, dan dapat disimpulkan tes keterampilan proses sains adalah reliabel.

Pengumpulan data menggunakan metode dokumentasi dan tes. Data awal siswa berupa nama dan data nilai penilaian akhir semester ganjil mata pelajaran kimia tahun pelajaran 2018/2019 dilakukan dengan metode dokumentasi. Data ini adalah data sekunder yang dijadikan sebagai data pengetahuan awal siswa.

Nilai rata-rata pengetahuan awal dari 172 sampel penelitian adalah 54,12. Apabila nilai perolehan pengetahuan awal siswa $\geq$ 54,12, maka siswa dikategorikan mempunyai pengetahuan awal tinggi dan Siswa dikategorikan mempunyai pengetahuan awal rendah apabila nilai perolehan pengetahuan awal siswa $<54,12$.

Metode tes digunakan untuk memperoleh data keterampilan proses sains. Instrumen tes keterampilan proses sains berupa 22 soal pilihan ganda. Instrument tes digunakan pada kegiatan prates dan pascates.

Uji ANOVA (Analysis of Variance) digunakan pada pengujian hipotesis untuk mengetahui perbedaan keefektifan tingkatan pembelajaran inkuiri terhadap peningkatan keterampilan proses sains pada siswa dengan pengetahuan awal berbeda.

Berdasarkan kriteria pengujian data, terdapat perbedaan yang signifikan jika nilai signifikansi (sig) $<0,05$ dalam taraf signifikansi $(\alpha)=5 \%$ atau Fhitung $>$ Ftabel maka disimpulkan $\mathrm{H} 1$ diterima dan $\mathrm{HO}$ ditolak.

Prasyarat analisis yang harus dipenuhi untuk menggunakan anova adalah normalitas dan homogenitas dari variabel penelitian. Uji Kolmogorov-Smirnov digunakan untuk uji normalitas. Kriteria pengujian apabila nilai signifikansi (sig) >0,05 dalam taraf signifikansi $(\alpha)=5 \%$, maka data dinyatakan berdistribusi normal. Distribusi data pada uji normalitas dapat dilihat pada tabel 4 .

Tabel 4. Distribusi Data Pada Uji Normalitas

\begin{tabular}{lccl}
\hline \multicolumn{1}{c}{ Variabel } & $\begin{array}{c}\text { Tingkatan } \\
\text { Inkuiri }\end{array}$ & Signifikansi & Keterangan \\
\hline Pengetahuan & PIT-2 & $\mathbf{0 , 0 9 3}$ & Berdistribusi Normal \\
Awal & PIT-3 & $\mathbf{0 , 1 9 3}$ & Berdistribusi Normal \\
& PIT-4 & $\mathbf{0 , 0 7 3}$ & Berdistribusi Normal \\
\hline Keterampilan & PIT-2 & $\mathbf{0 , 2 0 0}$ & Berdistribusi Normal \\
Proses sains & PIT-3 & $\mathbf{0 , 2 0 0}$ & Berdistribusi Normal \\
(Pretest) & PIT-4 & $\mathbf{0 , 2 0 0}$ & Berdistribusi Normal \\
\hline Keterampilan & PIT-2 & $\mathbf{0 , 1 7 9}$ & Berdistribusi Normal \\
Proses sains & PIT-3 & 0,081 & Berdistribusi Normal \\
(Prosttest) & PIT-4 & $\mathbf{0 , 0 7 9}$ & Berdistribusi Normal \\
\hline
\end{tabular}


Uji Levene's Test digunakan untuk uji homogenitas/variansi data antar kelompok. Kriteria pengujian apabila nilai signifikansi (sig) $>0,05$ dalam taraf signifikansi $(\alpha)=5 \%$, maka variansi data antar kelompok dinyatakan sama atau homogen. Variansi data antar kelompok ditunjukkan pada tabel 5 .

\section{Tabel 5. Variansi Data Antar Kelompok}

\begin{tabular}{lcc}
\hline \multicolumn{1}{c}{ Variabel } & Signifikansi & Keterangan \\
\hline Pengetahuan Awal & 0,987 & Homogen \\
Keterampilan Proses sains (Pretest) & 0,949 & Homogen \\
Keterampilan Proses sains (Prosttest) & 0,786 & Homogen \\
\hline
\end{tabular}

Keterampilan proses sains dari masingmasing kelompok perlakuan dikatakan mengalami peningkatan, dapat diketahui dari data gain score berdasarkan persamaan yang dikembangkan oleh Hake (1998).

$$
g=\frac{S_{\text {pascates }}-S_{\text {prates }}}{S_{\text {maks }}-S_{\text {prates }}}
$$
Keterangan: g :gain score S pascates : skor pascates S prates : skor prates

Pada tabel 6 ditunjukkan kategori peningkatan keterampilan proses sains berdasarkan perolehan nilai gain score

Tabel 6. Kategori Perolehan Nilai Gain Score

\begin{tabular}{cc}
\hline Nilai & Kategori \\
\hline $\mathrm{g} \geq 0,7$ & Tinggi \\
$0,3 \leq \mathrm{g}<0,7$ & Sedang \\
$\mathrm{g}<0,3$ & Rendah \\
\hline
\end{tabular}

Sumber: Hake (1998)

\section{HASIL DAN PEMBAHASAN}

Tabel berikut menunjukkan data hasil penelitian yang telah didapat.

Tabel 7. Hasil Prates, Pascates dan Gain Score Keterampilan Proses Sains Berdasarkan Tingkatan Pembelajaran Inkuiri

\begin{tabular}{lcccccc}
\hline & \multicolumn{2}{c}{ Inkuiri Tk. 2 } & \multicolumn{2}{c}{ Inkuiri Tk. 3 } & \multicolumn{2}{c}{ Inkuiri Tk. 4 } \\
\cline { 2 - 7 } & Prates & Pascates & Prates & Pascates & Prates & Pascates \\
\hline Rata-Rata & 34,63 & 72,75 & 33,50 & 78,00 & 34,68 & 70,37 \\
$N$-Gain & \multicolumn{2}{c}{0,58} & & 0,67 & 0,55 \\
Kategori & \multicolumn{2}{c}{ Sedang } & \multicolumn{2}{c}{ Sedang } & \multicolumn{2}{c}{ Sedang } \\
\hline
\end{tabular}

Tabel 8. Hasil Prates, Pascates dan Gain Score Keterampilan Proses Sains Berdasarkan Pengetahuan Awal

\begin{tabular}{|c|c|c|c|c|}
\hline \multirow{2}{*}{$\begin{array}{l}\text { Pengetahuan } \\
\text { Awal }\end{array}$} & \multicolumn{2}{|c|}{ Tinggi } & \multicolumn{2}{|c|}{ Rendah } \\
\hline & Prates & Pascates & Prates & Pascates \\
\hline Rata-Rata & 40,55 & 81,44 & 28,13 & 66,21 \\
\hline $\begin{array}{l}N \text {-Gain } \\
\text { Kategori }\end{array}$ & \multicolumn{2}{|c|}{$\begin{array}{c}0,69 \\
\text { Sedano }\end{array}$} & \multicolumn{2}{|c|}{$\begin{array}{c}0,53 \\
\text { Sedano }\end{array}$} \\
\hline
\end{tabular}


Tabel 9. Hasil Prates, Pascates dan Gain Score Keterampilan Proses Sains Berdasarkan Tingkatan Pembelajaran Inkuiri dan Pengetahuan Awal

\begin{tabular}{|c|c|c|c|c|c|c|c|}
\hline \multirow{3}{*}{$\begin{array}{l}\text { Pengetahuan } \\
\text { Awal }\end{array}$} & \multirow{3}{*}{$\begin{array}{l}\text { Sumber } \\
\text { Statistik }\end{array}$} & \multicolumn{6}{|c|}{ Model Pembelajaran } \\
\hline & & \multicolumn{2}{|c|}{ Inkuiri Tk.2 } & \multicolumn{2}{|c|}{ Inkuiri Tk.3 } & \multicolumn{2}{|c|}{ Inkuiri Tk.4 } \\
\hline & & Prates & Pascates & Prates & Pascates & Prates & Pascates \\
\hline \multirow[b]{2}{*}{ Tinggi } & Rata-Rata & 42,23 & 82,08 & 37,90 & 84,57 & 41,79 & 77,62 \\
\hline & $\begin{array}{l}N \text {-Gain } \\
\text { Kategori }\end{array}$ & \multicolumn{2}{|c|}{$\begin{array}{c}0,69 \\
\text { Sedang }\end{array}$} & \multicolumn{2}{|c|}{$\begin{array}{c}0,75 \\
\text { Tinggi }\end{array}$} & \multicolumn{2}{|c|}{$\begin{array}{c}0,62 \\
\text { Sedang }\end{array}$} \\
\hline Rendah & $\begin{array}{l}\text { Rata-Rata } \\
\mathrm{N} \text {-Gain } \\
\text { Kategori }\end{array}$ & $\begin{array}{r}28,26 \\
S\end{array}$ & $\begin{array}{l}511^{64,94} \\
\text { lang }\end{array}$ & & $\begin{array}{l}70,96 \\
59^{\text {ang }}\end{array}$ & & $\begin{array}{l}49^{62,86} \\
\text { tang }\end{array}$ \\
\hline
\end{tabular}

Tabel 10. Hasil Uji Anova

\begin{tabular}{|c|c|c|c|c|c|}
\hline \multicolumn{6}{|c|}{$\begin{array}{l}\text { Tests of Between-Subjects Effects } \\
\end{array}$} \\
\hline \multicolumn{6}{|c|}{ Dependent Variable: Keterampilan Proses Sains } \\
\hline Source & $\begin{array}{l}\text { Type III } \\
\text { Sum of } \\
\text { Squares }\end{array}$ & df & $\begin{array}{l}\text { Mean } \\
\text { Square }\end{array}$ & F & Sig. \\
\hline Corrected Model & $11695.393^{\mathrm{a}}$ & 5 & 2339.079 & 46.146 & .000 \\
\hline Intercept & 934767.519 & 1 & 934767.519 & 18441.383 & .000 \\
\hline TINGKATAN INKUIRI & 1637.855 & 2 & 818.928 & 16.156 & .000 \\
\hline K_PENGETAHUAN AWAL & 9863.204 & 1 & 9863.204 & 194.584 & .000 \\
\hline TINGKATAN INKUIRI * & 92.892 & 2 & 46.446 & .916 & .402 \\
\hline K_PENGETAHUAN AWAL & & & & & \\
\hline Error & 8414.304 & 166 & 50.689 & & \\
\hline Total & 955186.000 & 172 & & & \\
\hline Corrected Total & 20109.698 & 171 & & & \\
\hline
\end{tabular}

Peningkatan Keterampilan Proses Sains Berdasarkan Tingkatan Pembelajaran Inkuiri

Pada tabel 10 hasil uji anova peningkatan keterampilan proses sains pada penerapan tingkatan pembelajaran inkuiri diperoleh nilai signifikan $($ sig $)=0,000$ dan nilai Fhitung $=$ 16,156 . Nilai $\mathrm{F}$ tabel pada taraf signifikan $(\alpha)$ $=5 \%, F(0,05: 2,166)=3,057$. Sebab nilai sig. $0,000<$ taraf signifikansi $(0,05)$ atau Fhitung $(16.156)>$ Ftabel $(3,057)$ maka $\mathrm{H} 1$ diterima dan HO ditolak, bisa disimpulkan penerapan pembelajaran inkuiri tingkat 2 (PIT-2), tingkat 3 (PIT-3) dan tingkat 4 (PIT-4) mempunyai keefektifan yang berbeda secara signifikan terhadap peningkatan keterampilan proses sains.

Pasca pengujian anova, dilakukan uji Scheffe untuk mengetahui perbedaan antar kelompok perlakuan pembelajaran inkuiri terhadap peningkatan keterampilan proses sains. Perbedaan antar kelompok perlakuan dengan uji Scheffe diperlihatkan pada tabel 11.

Tabel 11. Perbedaan Antar Kelompok Perlakuan Berdasarkan Uji Scheffe

\begin{tabular}{|c|c|c|c|c|c|c|}
\hline \multicolumn{6}{|c|}{ Multiple Comparisons } & \\
\hline \multicolumn{7}{|c|}{ Dependent Variable: Keterampilan Proses Sains } \\
\hline \multicolumn{7}{|c|}{ Scheffe } \\
\hline \multirow{2}{*}{$\begin{array}{c}\text { (I) } \\
\text { Tingkatan } \\
\text { Inkuiri }\end{array}$} & \multirow{2}{*}{$\begin{array}{c}\text { (J) } \\
\text { Tingkatan } \\
\text { Inkuiri }\end{array}$} & \multirow{2}{*}{$\begin{array}{c}\text { Mean } \\
\text { Difference } \\
(\mathrm{I}-\mathrm{J})\end{array}$} & \multirow{2}{*}{$\begin{array}{l}\text { Std. } \\
\text { Error }\end{array}$} & \multirow{2}{*}{ Sig. } & $\begin{array}{c}95 \% \\
\text { Confidence } \\
\text { Interval }\end{array}$ & $\begin{array}{c}95 \% \\
\text { Confidence } \\
\text { Interval }\end{array}$ \\
\hline & & & & & $\begin{array}{l}\text { Lower } \\
\text { Bound }\end{array}$ & $\begin{array}{l}\text { Upper } \\
\text { Bound } \\
\end{array}$ \\
\hline \multirow[t]{2}{*}{ PIT-2 } & PIT-3 & $-5.25^{*}$ & 1.328 & .001 & -8.53 & -1.97 \\
\hline & PIT-4 & 2.39 & 1.334 & .205 & -.91 & 5.68 \\
\hline \multirow[t]{2}{*}{ PIT-3 } & PIT-2 & $5.25^{*}$ & 1,328 & .001 & 1.97 & 8.53 \\
\hline & PIT-4 & $7.63^{*}$ & 1.328 & .000 & 4.35 & 10.91 \\
\hline \multirow[t]{2}{*}{ PIT-4 } & PIT-2 & -2.39 & 1.334 & .205 & -5.68 & .91 \\
\hline & PIT-3 & $-7.63^{\circ}$ & 1.328 & .000 & -10.91 & -4.35 \\
\hline
\end{tabular}


Antar kelompok perlakuan tingkatan pembelajaran inkuiri terdapat perbedaan jika nilai signifikansi (sig.) $<0,05$. Dari tabel 11 diketahui penerapan pembelajaran inkuiri tingkat 2 (PIT-2) berbeda secara signifikan dengan pembelajaran inkuiri tingkat 3 (PIT3) dan penerapan pembelajaran inkuiri tingkat 3 (PIT-3) berbeda secara signifikan dengan pembelajaran inkuiri tingkat 4 (PIT4). Penerapan pembelajaran inkuiri tingkat 2 (PIT-2) tidak berbeda secara signifikan dengan penerapan pembelajaran inkuiri tingkat 4 (PIT-4) pada peningkatan keterampilan proses sains.

Perbedaan peran guru dan siswa dalam penerapan tingkatan pembelajaran inkuiri, menyebabkan adanya perbedaan yang signifikan penerapan PIT-2, PIT-3 dan PIT4 terhadap peningkatan keterampilan proses sains. Pada PIT-2 siswa belajar cara menjelaskan hasil penelitian dan menarik kesimpulan (siswa hanya berpartisipasi pada fase sesudah pengalaman laboratorium, fase sebelum dan fase pengalaman laboratorium didominasi oleh guru). Pada PIT-3 siswa didorong untuk memimpin dalam fase pengalaman laboratorium dimana pada fase ini siswa secara mandiri atau dalam tim melakukan percobaaan untuk mengamati dan mengumpulkan data percobaan. Pada PIT-4 siswa berpartisipasi dalam semua fase pembelajaran inkuiri (merencanakan dan merancang kegiatan penyelidikan, melakukan pengamatan, menjelaskan hasil penelitian dan menarik kesimpulan), guru berperan dalam pengajuan masalah penyelidikan.

Dari tabel 7 dapat diketahui nilai ratarata prates dan pascates dari masing-masing kelompok perlakuan yang mengalami peningkatan. Pada kelompok eksperimen 1 (PIT-3) mengalami peningkatan gain score sebesar 0,67 dengan kategori peningkatan sedang, nilai rata-rata prates sebesar 33,50 dan pascates sebesar 78,00 . Pada kelompok eksperimen 2 (PIT-4) nilai rata-rata prates sebesar 34,68 dan pascates sebesar 70,37 dengan peningkatan gain score sebesar 0,55 dengan kategori peningkatan sedang. Pada kelompok kontrol dengan penerapan PIT-2 nilai rata-rata prates sebesar 34,63 dan pascates sebesar 72,75 dengan peningkatan gain score sebesar 0,58 dengan kategori peningkatan sedang. Peningkatan gain score penerapan PIT-2 pada kelompok kontrol dan penerapan PIT-4 pada kelompok eksperimen 2 terhadap penerapan PIT-3 pada kelompok eksperimen 1 menunjukkan rentang perbedaan yang besar. Peningkatan gain score penerapan PIT-4 pada kelompok eksperimen 2 terhadap penerapan PIT-2 pada kelompok kontrol menunjukkan peningkatan yang tidak berbeda jauh.

Penelitian lain yang sesuai dengan penelitian ini diantaranya: Hardianti \& Kuswanto (2017) menyimpulkan penerapan pembelajaran inkuiri tingkat 2 (PIT-2), PIT-3 dan PIT-4 berbeda secara signifikan terhadap peningkatan keterampilan proses sains. Hairani, dkk. (2016) menyimpulkan ada perbedaan keterampilan proses siswa antara pembelajaran langsung, inkuiri terbimbing dan inkuiri terbimbing dengan mind mapping terhadap keterampilan proses sains. Ramdan \& Hamidah (2015) menyimpulkan N-Gain keterampilan proses sains meningkat sebesar 0,57 pada penggunaan Levels of Inquiry dalam pembelajaran. Ariani, dkk. (2015) menyimpulkan penerapan pembelajaran inkuiri dapat meningkatkan KPS siswa sebesar $23,86 \%$. Iswatun, dkk. (2017) menyimpulkan kelas eksperimen mengalami peningkatan keterampilan proses sains sebesar 0,52 pada penerapan pembelajaran inkuiri. Penelitian Ergul, dkk (2011), Puspaningtyas \& Suparno (2017), Hartini (2017) dan Fatwa, dkk. (2018) juga menyimpulkan keterampilan proses sains dapat ditingkatkan secara signifikan melalui penerapan model pembelajaran inkuiri. Purwanto, dkk. (2013) kemampuan siswa untuk berinkuiri dapat dilatih melalui penerapan pembelajaran inkuiri.

Fadli (2019) menyimpulkan keaktifan dan kemampuan berpikir kritis siswa dapat ditingkatkan melalui penerapan model pembelajaran inkuiri. Irfan N, dkk. (2016) menyimpulkan keterampilan abad 21 dapat ditingkatkan melalui pembelajaran inkuiri.

\section{Peningkatan Keterampilan Proses Sains Berdasarkan Pengetahuan Awal}

Pada tabel 10 uji Anova keterampilan proses sains berdasarkan pengetahuan awal diperoleh nilai signifikansi (sig.) $=0,000$ dan 
Fhitung $=194,584$. Pada taraf signifikansi $(\alpha)$ $=5 \%$ diperoleh $\mathrm{F}$ tabel $(0,05: 1,166)=3,907$. Sebab nilai sig. $(0,000)<$ taraf signifikansi $(0,05)$ dan Fhitung $=194,584>\mathrm{F}$ tabel $(3,907)$, maka $\mathrm{H} 1$ diterima dan $\mathrm{HO}$ ditolak dan bisa disimpulkan peningkatan keterampilan proses sains secara signifikan dipengaruhi oleh pengetahuan awal siswa.

Dari tabel 8 perbedaan pengetahuan awal siswa yang secara signifikan berpengaruh terhadap keterampilan proses sains terlihat dari perolehan nilai rata-rata prates dan pascates keterampilan proses sains. Peningkatan gain score sebesar 0,69 dengan kategori peningkatan sedang terjadi pada siswa dengan pengetahuan awal tinggi. Nilai prates dan pascates siswa sebesar 40,55 dan 81,44. Siswa dengan pengetahuan awal rendah memperoleh nilai prates dan pascates sebesar 28,13 dan 66,21 dengan peningkatan gain score sebesar 0,53 dengan kategori peningkatan sedang. Perolehan tes pada siswa dengan pengetahuan awal tinggi menunjukkan hasil yang lebih tinggi dari perolehan tes siswa dengan pengetahuan awal rendah.

Dalam kegiatan pembelajaran terkadang pengetahuan awal menjadi prasyarat yang dibutuhkanuntukdapatmengikutipembelajaran pada konsep yang lebih tinggi. Pengetahuan awal dapat berupa pengetahuan, keterampilan dan kemampuan yang telah diperoleh atau dikuasai sebagai hasil dari tindak belajar. Siswa yang memiliki pengetahuan awal tinggi lebih mudah untuk dapat melaksanakan proses belajar pada konsep yang lebih tinggi karena mereka mampu menghubungkan konsep, prinsip, fakta serta informasi relevan yang telah dipelajari dengan konsep baru yang dipelajari dibandingkan siswa dengan pengetahuan awal rendah. Dalam mempelajari materi/konsep berikutnya, siswa dengan pengetahuan awal tinggi memiliki tingkat kesiapan belajar yang tinggi dibandingkan dengan siswa dengan kemampuan awal rendah.

Penelitian lain yang sejalan dengan hasil penelitian ini adalah penelitian yang dilakukan Hairani, dkk. (2016), Effendi (2016) dan Fatwa, dkk. (2018) yang menyimpulkan bahwa ada perbedaan keterampilan proses sains pada siswa dengan kategori pengetahuan awal tinggi dan rendah.
Peningkatan Keterampilan Proses Sains Berdasarkan Pengaruh Bersama Tingkatan Pembelajaran Inkuri dan Pengetahuan Awal

Hasil uji Anova pada tabel 10 peningkatan keterampilan proses sains berdasarkan pengaruh bersama tingkatan pembelajaran inkuiri dan pengetahuan awal diperoleh nilai signifikansi (sig.) =0,402 dan Fhitung =0,916. $F$ tabel untuk taraf signifikansi $(\alpha)=5 \%$ $F(0,05 ; 2,166)$ diperoleh harga $=3,057$. Karena nilai sig. $(0,402)>$ taraf signifikansi $(0,05)$ dan Fhitung $(0,916)<$ Ftabel $(3,057)$ maka $\mathrm{HO}$ diterima dan $\mathrm{H} 1$ ditolak, bisa diambil kesimpulan bahwa tingkatan pembelajaran inkuiri dan pengetahuan awal tidak memberikan pengaruh bersama terhadap peningkatan keterampilan proses sains.

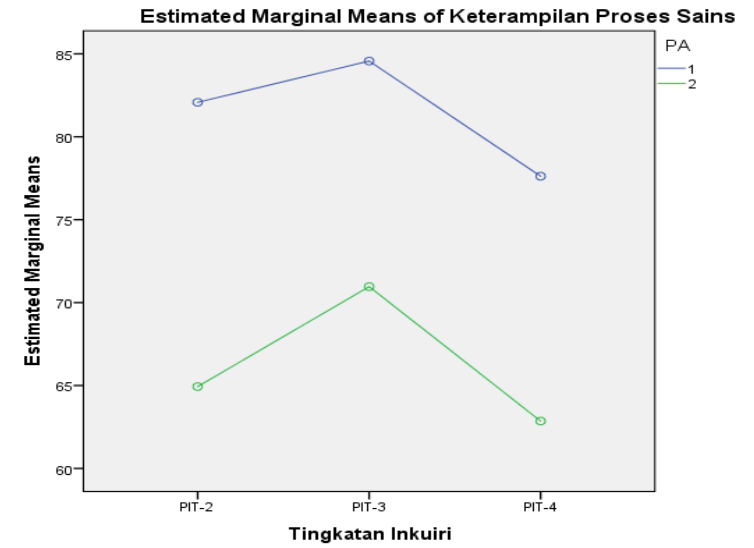

Gambar 2. Pengaruh Bersama Tingkatan Pembelajaran Inkuiri dan Pengetahuan Awal Terhadap keterampilan Proses Sains

Gambar 2 terlihat bahwa kedua garis yang mewakili pengetahuan awal siswa dengan kategori tinggi dan rendah pada penerapan pembelajaran inkuiri tingkat 2 (PIT-2), tingkat 3 (PIT-3) dan tingkat 4 (PIT-4) menunjukkan tidak bersilangan, keadaan ini menunjukkan pola yang sama bahwa nilai Keterampilan proses sains yang diperoleh siswa dengan kategori pengetahuan awal tinggi lebih tinggi dari nilai yang diperoleh siswa dengan kategori pengetahuan awal rendah pada perlakuan pembelajaran yang sama.

Penelitian Fatwa, dkk. (2018) sejalan dengan hasil penelitian ini yang menyimpulkan tingkatan pembelajaran inkuiri dan pengetahuan awal tidak memberikan pengaruh secara bersama terhadap peningkatan keterampilan proses 
sains. Hairani, dkk. (2016) memberikan kesimpulan berbeda yang menyatakan model pembelajaran inkuiri dan pengetahuan awal memberikan pengaruh secara Bersama terhadap keterampilan proses sains.

Keefektifan Tingkatan Pembelajaran Inkuiri Berdasarkan Peningkatan Keterampilan Proses Sains Pada Pengetahuan Awal Berbeda

Peningkatan keterampilan proses sains dengan penerapan tingkatan pembelajaran inkuiri pada kategori pengetahuan awal tinggi dan rendah dideskripsikan pada tabel 9. Siswa dengan kategori pengetahuan awal tinggi pada penerapan PIT-3 mengalami peningkatan (gain score) keterampilan proses sains sebesar 0,75 dengan kategori peningkatan tinggi. Pada Penerapan PIT-4 mengalami peningkatan (gain score) sebesar 0,62 dengan kategori peningkatan sedang dan pada penerapan PIT-2 mengalami peningkatan (gain score) sebesar 0,69 dengan kategori peningkatan sedang.

Siswa dengan kategori pengetahuan awal rendah pada penerapan PIT-3 mengalami peningkatan (gain score) keterampilan proses sains sebesar 0,59 dengan kategori peningkatan sedang. Pada Penerapan PIT-4 mengalami peningkatan (gain score) sebesar 0,49 dengan kategori peningkatan sedang dan pada penerapan PIT-2 mengalami peningkatan (gain score) sebesar 0,51 dengan kategori peningkatan sedang.

Peningkatan (gain score) keterampilan proses sains pada penerapan tingkatan pembelajaran inkuiri dengan pengetahuan awal berbeda ditunjukkan pada gambar 3 .

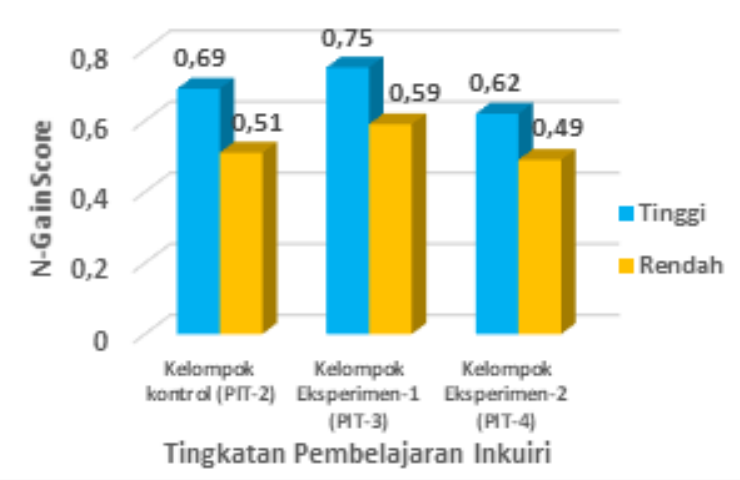

\footnotetext{
Gambar 3. Peningkatan (Gain Score) Keterampilan Proses Sains pada Penerapan Tingkatan Pembelajaran Inkuiri Dengan Pengetahuan Awal Berbeda
}

Dari gambar 3 dapat disimpulkan bahwa peningkatan (gain score) keterampilan proses sains pada penerapan pembelajaran inkuiri tingkat 3 (PIT-3) memperoleh nilai lebih tinggi dibanding pembelajaran inkuiri tingkat 2 (PIT2) dan tingkat 4 (PIT-4) pada siswa dengan pengetahuan awal yang berbeda. Keadaan ini menunjukkan bahwa pada kategori pengetahuan awal tinggi maupun rendah, penerapan pembelajaran inkuiri tingkat 3 (PIT-3) paling efektif dalam meningkatkan keterampilan proses sains.

\section{SIMPULAN}

Dari hasil penelitian dan pembahasan yang telah dilakukan, dapat diambil kesimpulan: (1) Pembelajaran inkuiri tingkat 2 (PIT-2), tingkat 3 (PIT-3) dan tingkat 4 (PIT-4) mempunyai perbedaan keefektifan terhadap peningkatan keterampilan proses sains. (2) Peningkatan keterampilan proses sains secara signifikan dipengaruhi oleh pengetahuanawal siswayang berbeda. (3) Tingkatan pembelajaran inkuiri dan pengetahuan awal tidak memberikan pengaruh secara bersama terhadap peningkatan keterampilan proses sains. (4) pada kategori pengetahuan awal tinggi maupun rendah, penerapan pembelajaran inkuiri tingkat 3 (PIT-3) paling efektif dari PIT-2 dan PIT-4 dalam meningkatkan keterampilan proses sains.

\section{DAFTAR PUSTAKA}

Abungu, H. E., Mark I. O.,\& Samuel, W. 2014. The Effect of Science Process Skill Teaching Approach on Secondary School: Achievement in Chemistry in Nyando District. Kenya. Journal of Education and Sosial Research. 4 (6). 559-371

Ariani, Mika., Hamid, Abdul. \& Leni. 2015. Meningkatkan Keterampilan Proses Sains dan Hasil Belajar Siswa Pada Materi Koloid Dengan Model Inkuiri Terbimbing (Guided Inkuiri) Pada Siswa Kelas XI IPA 1 SMA Negeri 11 Banjarmasin. Quantum: Jurnal Inovasi Pendidikan Sains. v.6.n.1.p,98-107.

Effendi, M. 2016. Pengaruh Model Pembelajaran ECIRR Terhadap Penguasaan Konsep Fisika Pada Siswa SMK. Jurnal Pendidikan Sains. 4 (3). 113-121. 
Ergul, Simsekti., Calis \& Gocmencelebi. 2011. The Effect of Inquiry-Based Science Teaching on Elementary School Students Science Process Skill and Science Attitudes. Bulgarian Journal of Science and Education Policy (BJSEP). 5 (1): 48-67Fadli, Failasuf. 2019. Penerapan Metode Inkuiri Dalam Meningkatkan Keterampilan Berpikir Kritis dan Keaktifan Belajar Siswa Pada Mata Pelajaran PAI di MTs Al-Amin Pekalongan. Edcomtech: Jurnal Kajian Teknologi Pendidikan. v. 4. n.1. p. 19-27. pISSN: 2548-9879 eISSN: 2599-2139.

Fatwa, Mohammad Wawan., Harjono, A., \& Jamaluddin. 2018. Pengaruh Model Pembelajaran Inkuiri Terbimbing Terhadap Keterampilan Proses dan Penguasaan Konsep Sains Ditinjau Dari Pengetahuan Awal Peserta Didik. Jurnal Pendidikan Fisika dan Teknologi. v.4. n.1. p. 121-130.

Hairani., Dasna, I Wayan., \& Koeshandayanto, S. 2016. Pengaruh Model Pembelajaran Inkuiri Terbimbing Berbantuan Mind Mapping Terhadap Keterampilan Proses Sains dan Prestasi Belajar IPA Siswa SMP Kelas VII Pada Pengetahuan Awal Berbeda. Jurnal Pendidikan dan Pembelajaran. v. 23. n.2.

Hake, Richard R. 1998. Interactive-Engagement Versus Traditional Methods: A SixThousand-Student Survey of Mechanics Test Data for Introductory Physics Course. American Journal of Physics, v.66. n. 1. P. 64-74.

Hanson, R., Taale, K.D., \& Antwi, V. 2011. Invertigating Senior High School Students Conceptions of Introductory Chemistry Concepts. International Journal of Educational Administration. 3 (1): 41-57.

Hardianti, Tuti., \& Kuswanto, Heru. 2017. Difference Among Levels of Inquiry: Process Skill Improvement at Senior High School in Indonesia. International Journal of Instruction. v.10. n. 2. p. 119-130.

Hartini, Ratih Indah Puji. 2017. Penggunaan Levels of Inquiry Dalam Meningkatkan Keterampilan Proses Sains Siswa. Jurnal IImu Pendidikan Fisika. v. 2. N.1. p. 19-24. p-ISSN: 2477-5959, e-ISSN:2477-8451.
Irfan N, Mochammad., Utari, Setiya., \& Liliawati, Winny. 2016. Penerapan Levels of Inquiry Dalam Pembelajaran IPA-Fisika Untuk Meningkatkan Keterampilan Abad Ke-21 (4C's) Pada Siswa SMP. Prosiding SNIPS 2016. Universitas Pendidikan Indonesia.

Iswatun, I., Mosik, M., \& Subali, Bambang. 2017. Penerapan Model Pembelajaran Inkuiri Terbimbing Untuk Meningkatkan KPS dan Hasil Belajar Siswa SMP Kelas VIII. Jurnal Inovasi Pendidikan IPA. v. 3 (2). p. $150-160$.

Kean, E. \& Middlecamp, C. 1985. Panduan Belajar Kimia Dasar. Jakarta: Gramedia.

Llewellyn, Douglas J. 2011. Differentiated Science Inquiry. California: Corwin A Sage Publications Company.

Matthew, B., \& Kenneth, I. 2013. A Study on The Effectc of Guided Inquiry Teaching Method on Students Achievement in Logic. International Research. 2(1): 134140.

Muslich, Masnur. 2007. KTSP (Kurikulum Tingkat Satuan Pendidikan) Dasar Pemahaman dan Pengembangan. Jakarta: Bumi Aksara.

Purwanto., Liliawati, Winny., \& Hidayat, Rahmat. 2013. Analisis Kemampuan Inkuiri dan Hasil Belajar Siswa Sekolah Menengah Pertama Melalui Model Pembelajaran Berbasis Model Hierarki of Inquiry. Prosiding Pertemuan IImiah XXVII HFI Jateng \& DIY. UPI Bandung.

Puspaningtyas, Khaireni., \& Suparno. 2017. Pengaruh Penerapan Model Inkuiri Terbimbing Terhadap Kemampuan Analisis dan Keterampilan Proses Sains. IJOSE: Indonesia Journal of Science and Education. v.1. n.1. P. 8-16. p-ISSN:2598-5213. e-ISSN: 2598-5205.

Ramdan, Sahri., \& Hamidah, Ida. 2015. Peningkatan Keterampilan Proses Sains Siswa SMP Melalui Penerapan Levels of Inquiry Dalam Pembelajaran IPA Terpadu. Edusains (The Natural Science Education, Biology Education, Physics Education and Chemistry Education Journal). v.7. n.02. p. 106-113. p-ISSN:1979-7281, e-ISSN: 2443-1281.

Rauf, R.A.A., Rasul, M.S., Mansor, A.N., Othman, 
Z. \& Lyndon. 2013. Inculcation of Science Process Skills in a Science Classroom. Journal Asian Sosial Science. 9 (8). 47-57

Ristiyani, Erika., \& Bahriah, Evi Sapinatul. 2016. Analisis Kesulitan Belajar Kimia Siswa Di SMAN X Kota Tangerang Selatan. JPPI: Jurnal Penelitian dan Pembelajaran IPA. e-ISSN: 2477-2038. v.2. n.1. p. 18-29. Rustaman, N,. Dirdjosoemarto, S., Yudianto, S.A., Achmad, Y., Subekti, R., Rochintaniawati, D., Nurjhani, M. 2005. Strategi Belajar Mengajar Biologi. Malang: UM Press.

Setyosari, Punaji. 2014. Menciptakan Pembelajaran Yang Efektif dan Berkualitas. Jinotep: Jurnal Inovasi dan Teknologi Pembelajaran. v.1. n.1. p. 20-31.

Sukarno, S., Permanasari, A., dan Hamidah, I. 2013. The Profile of Science Process Skill (SPS) Student at Secondary High School
(Case Study in Jambi). International Journal of Scientific Engineering and Research (IJSER). www.ijser.in. ISSN. 1 (1). 2347-3878.

Sutman, J., Schmuckler, J.S., \& Joyce D.W. 2008. The Science Quest: Using Inquiry/ Discovery to Enchange Student Learning. New Jersey: Jossey-Bass.

Wedi, Agus. 2016. Konsep dan Masalah Penerapan Metode Pembelajaran: Upaya Peningkatan Mutu Pembelajaran Melalui Konsistensi Teoritis-Praktis Penggunaan Metode Pembelajaran. Edcomtech: Jurnal Kajian Teknologi Pendidikan. pISSN: 25489879 eISSN: 2599-2139. v.1. n.1. p. 21-28.

Wenning, C.J. \& Mansoor, A.K. 2011. Levels of Inquiry of Science Teaching: Learning Sequences to Lesson Plants. Journal of Physics Teacher Education Online. 6(2). 17-20 